\title{
PERKEMBANGAN ULAT BUAH Heliothis armigera (Lepidoptera:Noctuidae) PADA BEBERAPA VARIETAS KACANG KEDELAI (Glycine max L.)
}

\author{
Parluhutan Siahaan ${ }^{1)}$ dan Redsway D.T. Maramis ${ }^{2)}$ \\ ${ }^{1)}$ PS Biologi, FMIPA Unsrat, Jl. Kampus Unsrat Manado \\ ${ }^{2)}$ Jurusan Hama dan Penyakit, Fakultas Pertanian Unsrat, Jl. Kampus Unsrat Manado \\ e-mail: luhut.siahaan68@gmail.com ; redsway.maramis@yahoo.com
}

\begin{abstract}
ABSTRAK
Telah dilakukan percobaan untuk melihat pengaruh beberapa varietas kacang kedelai (grobogan, willis, sinabung dan gepakijo) terhadap perkembangan ulat buah Heliothis armigera karena serangga ini adalah hama penting terhadap tanaman ini. Hasilnya menunjukkan bahwa waktu yang dibutuhkan oleh sebutir telur untuk menetas tidak berbeda pada semua varietas yang diujikan. Hal sama juga terjadi pada persentase jumlah telur yang menetas pada keempat varietas tersebuttidak berbeda. Secara umum terlihat bahwa untuk semua parameter yaitu fase larva, fase pupa, fase imago dan keperidian serangga yang dipelihara pada kedelai varietas willis dan sinabung tidak ada perbedaan, tetapi berbeda nyata apabila dibandingkan dengan yang dipelihara pada varietas grobagan. Sedangkan yang berkembang pada varietas grobogan berbeda nyata dengan yang berkembang pada varietas gepak ijo. Dapat disimpulkan bahwa varietas gepak ijo adalah varietas yang paling baik dalam menekan perkembangan serangga $H$. armigera.
\end{abstract}

Kata kunci: ulat buah, kacang kedelai

\section{THE DEVELOPMENT OF COOTON BOLLWORM Heliothis armigera (Lepidoptera:Noctuidae) ON SOME SOYBEAN VARIETIES (Glycine max L.)}

\begin{abstract}
Experiments were conducted to see the effect of some soybean varieties (Grobogan, willis, sinabung and gepakijo) on the development of cotton bollworm Heliothis armigera because this insect is an important pest on this crop. The results showed that the time taken by an egg to hatch is not different at all tested varieties. The same thing also happened on the percentage of eggs that hatch in four varieties are no different. In general, it appears that for all the parameters, namely the phase larva, pupa, imago and fecundity of insects reared on soybean varietiess sinabung and willis is no difference, but significantly different when compared to those reared on varieties grobogan. While evolving at significantly different Grobogan varieties that thrive on gepak ijo varieties. It can be concluded that gepak ijo varieties are the best varieties in suppressing the development of $H$. armigera.
\end{abstract}

Keywords: Cooton bollworm, soybean

\section{PENDAHULUAN}

Ulat buah, Heliothis armigera (Hübner) (Lepidoptera: Noctuidae) adalah hama penting yang menyerang berbagai tanaman penting di Indonesia (Setiawati, 1991). Ngengat hama ini mampu menyebar jauh mengikuti arah angin atau menentang arah angin (Farrow \& Daly, 1987). Serangga ini juga bersifat polifag, tanaman yang sering diserangnya adalah tomat dan kedelai. Kerusakan oleh larva $H$. armigera pada buah tomat dapat mencapai $80 \%$ (Uhan dan Suriaatmadja, 1993), sedangkan pada polong kedelai dapat mencapai 35,50\% (Herlinda et al., 1999).

Larva dari serangga ini dapat menyerang hamper semua bagian tanaman (batang, daun bunga dan buah) sehingga serangga ini sangat menimbulkan masalah yang sangat serius bagi para petani. (Liu et al. 2004). Mengatasi hama ini dengan cara cepat adalah dengan menggunakan pestisida kimia sintetik, akan tetapi penggunaan pestisida sintetik ternyata menimbulkan berbagai masalah lain diantaranya terjadinya resistensi pada serangga, kontaminasi lingkungan, berkurangnya keanekaragaman 
hayati serta masalah-masalah kesehatan (Naseri et al. 2009).

Untuk meningkatkan produksi hasil pertanian kacang kedelai, maka Balai penelitian tanaman kacang dan umbi (Balitkabi) Malang telah melepaskan beberapa varietas kacang kedelai ke pasar. Beberapa diantara varietas tersebut adalah varietas Grobogan, Willis, sinabung, Gepak Kuning, Gepak Hijau, Detam , Detam 2 dan lain-lain. Di ladang pertanian varietasvarietas tersebut tentu akan diserang oleh hama dan salah satunya adalah ulat buah $H$. armigera.

Kemampuan serangga ulat buah $H$. armigera untuk menyerang berbagai varietas kacang kedelai bisa saja tidak sama. Sifatsifat fisik tanaman seperti ketebalan daun, banyaknya bulu-bulu pada tanaman, dan kandungan kimiawi tanaman seperti komposisi nutrisi dan keberadaan senyawa alelokimia akan mempengaruhi besarnya serangan hama terhadap inangnya (Fisher et al., 2000).

Untug (2006) menyatakan bahwa sifat fisiologi dari tanaman dapat mempengaruhi serangga, sifat fisiologi itu biasanya berupa zat-zat kimia yang dihasilkan oleh proses metabolisme tanaman, baik yang berupa metabolisme primer maupun yang berupa metabolisme sekunder. Hasil metabolisme primer seperti karbohidrat, lemak, protein, hormone, enzim, senyawa-senyawa organik oleh tanaman digunakan untuk pertanaman dan pembiakan tanaman. Namun demikian beberapa hasil metabolisme primer tersebut juga dapat menjadi perangsang makan, bagian dari nutrisi serangga atau mungkin juga dapat sebagai racun.

Setiap varietas tanaman kedelai yang dilepaskan ke petani oleh Balitkabi tentu saja memiliki variasi satu dengan yang lain dalam hal sifat-sifat fisiologinya. Sifat-sifat fisiologi tanaman akan mempengaruhi kemampuan serangga dalam menyerang tanaman, perkembangan serangga dan kempuannya bereproduksi dengan demikian tentu saja akan ada variasi antar varietas kacang kedelai dalam menghadapi serangan dari hama ulat buah $H$. armigera.

Oleh karena itu perlu dilakukan penelitian varietas-varietas manakah dari kacang kedelai tersebut yang lebih tahan terhadap serangan larva ulat buah $H$. armigera. Hasil penelitian ini nantinya diharapkan dapat member rekomendasi bagi para petani kedelai, untuk memilih varietas mana yang lebih cocok untuk daerah mereka yang kondisinya paling banyak mengatasi masalah hama ulat buah $H$. armigera.

\section{BAHAN DAN METODE}

Perkembangan $H$. armigera diamati pada lama perkembangan telur, larva, pupa, lama hidup imago, daur hidup, mortalitas telur, dan keperidian pada empat varietas tanaman kedelai. Percobaan ini menggunakan ancangan acak lengkap (RAL) dengan empat perlakuan, yaitu kacang kedelai varietas Grobogan, varietas Willis, varietas Sinabung dan varietas Gepak Ijo yang dipelihara di laboratorium dengan suhu rata-rata $22^{\circ} \mathrm{C}$ dan kelembaban nisbi rata-rata $30-40 \%$. Percobaan ini dilakukan dengan menggunakan lima ulangan.

Perkembangan telur menggunakan ngengat $H$. armigera dari larva yang dibiakkan pada tanaman tomat di rumah kaca. Seratus telur yang diletakkan oleh ngengat pada waktu yang sama dimasukkan ke dalam wadah plastik kecil berukuran diameter $10 \mathrm{~cm}$ dan tinggi $70 \mathrm{~cm}$, berisi satu varietas tanaman kedelai dan untuk perlakuan lainnya dilakukan dengan cara yang sama tetapi dengan inang yang varietasnya berbeda. Supaya diperoleh seratus telur per perlakuan, maka diusahakan telur diletakkan lebih sehingga kelebihannya dapat dikurangi. Selanjutnya, diamati perkembangan dan mortalitas telur. Setiap dua jam, jumlah telur yang menetas dicatat. Percobaan ini diulang sebanyak lima kali.

Perkembangan larva diamati dari telur yang menetas pada waktu yang sama. Banyaknya larva yang diamati tergantung pada persentase penetasan pada percobaan perkembangan telur. Larva dimasukkan ke dalam satu wadah plastik kecil (diameter $10 \mathrm{~cm}$ dan tinggi $70 \mathrm{~cm}$ ) yang berisi satu varietas tanaman inang. Masingmasing lima perlakuan tanaman inang diletakkan dalam wadah plastik yang berbeda. Tanaman inang diganti setiap hari dengan yang baru hingga larva menjadi pupa. Setiap dua jam, jumlah larva yang menjadi 
pupa dicatat. Pengulangan percobaan ini dilakukan lima kali.

Pupa yang terbentuk pada hari yang sama ditempatkan pada wadah plastik (diameter $10 \mathrm{~cm}$, tinggi $15 \mathrm{~cm}$ ) yang sama dan pada wadah diberi label varietas inangnya. Berapa lama perkembangan pupa akan dihitung sejak pupa terbentuk hingga imago muncul. Oleh karena itu, jumlah pupa yang menjadi imago dicatat setiap hari hingga semuanya menjadi imago.

Sepuluh ekor imago yang baru muncul dari pupa tadi, lalu dipindahkan ke wadah plastik (diameter $10 \mathrm{~cm}$ dan tinggi $70 \mathrm{~cm}$ ) diamati hingga mati sehingga didapatkan data lama hidup. Percobaan ini diulang lima kali. Daur hidupnya adalah jumlah seluruh waktu pada fase telur, larva, pupa, dan waktu sejak imago terbentuk hingga meletakkan telur (masa praoviposisi).

Keperidian diamati pada seekor imago yang baru muncul dari pupa kemudian dimasukkan ke dalam satu wadah plastik kecil (diameter $10 \mathrm{~cm}$ dan tinggi $70 \mathrm{~cm}$ ) yang berisi satu varietas tanaman kedelai. Masingmasing lima perlakuan vaietas inang diletakkan dalam wadah plastik yang berbeda. Dilakukan pencatatan telur yang diletakkan setiap hari sampai imago mati. Sampai lima kali percobaan ini diulang.

Analisis Data. Perbedaan lama perkembangan di antara perlakuan dianalisis dengan ANOVA yang dilanjutkan dengan uji BNT pada taraf nyata $5 \%$, dengan bantuan program SPSS versi 10.

\section{HASIL DAN PEMBAHASAN}

Hasil penelitian terhadap pengaruh empat varietas tanaman kedelai terhadap lama fase telur $H$. armigera dapat dilihat pada tabel 1 .

Tabel 1. Rata-rata fase telur dan larva instar $1,2,3$, dan $4 \mathrm{H}$. armigera pada empat varietas tanaman kedelai

\begin{tabular}{|l|c|c|c|c|r|}
\hline \multirow{2}{*}{$\begin{array}{c}\text { Varietas } \\
\text { Inang }\end{array}$} & \multicolumn{5}{|c|}{ Rata-rata fase (hari) } \\
\cline { 2 - 6 } & Telur & L-Instar 1 & L-Instar 2 & L-Instar 3 & L-Instar 4 \\
\hline Grobogan & $4.33 \mathrm{a}$ & $3.97 \mathrm{a}$ & $3.89 \mathrm{~b}$ & $4.39 \mathrm{a}$ & $4.17 \mathrm{a}$ \\
\hline Willis & $4.36 \mathrm{a}$ & $3.09 \mathrm{~b}$ & $3.18 \mathrm{a}$ & $2.94 \mathrm{~b}$ & $3.83 \mathrm{~b}$ \\
\hline Sinabung & $4.03 \mathrm{a}$ & $3.22 \mathrm{~b}$ & $3.21 \mathrm{a}$ & $3.27 \mathrm{~b}$ & $3.62 \mathrm{~b}$ \\
\hline Gepak ijo & $4.05 \mathrm{a}$ & $4.13 \mathrm{a}$ & $3.99 \mathrm{~b}$ & $4.80 \mathrm{c}$ & $5.57 \mathrm{c}$ \\
\hline
\end{tabular}

Keterangan: Angka dalam lajur yang diikuti oleh huruf yang sama dibawahnya, tidak berbeda nyata (BNT, $\mathrm{P}<0.05)$

Lamanya waktu fase telur pada kelima varietas tumbuhan inang tersebut berkisar antara 4.03-4.36 hari. Perbedaan varietas tumbuhan inang tampaknya tidak menyebabkan perbedaan dalam hal waktu yang dibutuhkan telur untuk masuk ke dalam fase larva instar 1. Hal ini menunjukkan bahwa apapun varietas jenis inang dimana telur diletakkan tidak mempengaruhi perkembangan telur tersebut. Tidak adanya perbedaan disebabkan karena induk serangga yang menghasilkan telur tersebut diperbanyak pada tanaman tomat, sehingga yang mempengaruhi panjang pendeknya lama perkembangan telur dipengaruhi oleh jenis atau varietas makanannya (Jumar 2000).
Ada perbedaan lama fase larva instar satu bila berkembang pada varietas inang yang berbeda. Lama perkembangan fase instar satu paling panjang pada varietas gepak ijo (4,13 hari) yang tidak berbeda dengan isntar satu yang berkembang pada varietas grobogan yaitu 3,97 hari. Fase instar 1 yang paling singkat waktu perkembangannya terdapat pada varietas wilis yaitu 3,09 hari dan angka ini tidak berbeda nyata dengan yang berkembang pada varietas sinabung (3,22 hari) (Tabel 1).

Lama fase perkembangan larva instar dua dan tiga pada varietas willis dan varietas sinabung tidak berbeda nyata, akan tetapi kedua varietas ini memberikan perbedaan yang nyata dengan varietas 
grobogan dan kepak ijo. Sementara itu, lama fase perkembangan pada instar 1 dan instar 2 pada varietas grobogan dan gepak ijo juga tidak ada perbedaan nyata.

Fase perkembangan larva instar yang terakhir yaitu instar 4 yang terpendek terjadi pada varietas sinabung yaitu selama 3,62 hari tetapi tidak berbeda nyata dengan lama perkembangan yang terjadi pada varietas willis yaitu 3,83 hari. Fase perkembangan terlama untuk instar ke 4 terjadi pada varietas gepak ijo yaitu 5,57 hari yang kemudian dilanjutkan dengan yang terjadi pada varietas grobogan yaitu selama 4,17 hari (tabel 1)

Berdasarkan tabel 2 dapat dilihat lamanya rata-rata total waktu selama fase larva dan juga dapat lihat rata-rata waktu yang dibutuhkan selamaf ase pupa. Lama fase larva yang dimaksud di sini adalah jumlah total waktu yang dibutuhkan mulai dari menetas dari telur sampai dengan memasuki fase pupa atau dengan kata lain fase larva merupakan hasil penjumlahan lama fase larva instar 1, 2, 3 , dan 4 pada 4 varitas tumbuhan inang. Fase larva tersingkat terjadi pada larva yang berkembang pada tanaman kedelai varietaswillis yaitu 13.04 hari yang tidak berbeda nyata dengan fase larva pada varietas sinabung (13,32 hari) kedua kedua vaietas ini berbeda nyata dengan fase larva pada varietas grobogan dan varietas gepak ijo. Fase larva terlama terjadi pada varietas gepak ijo yaitu 18,49 hari yang berbeda nyata juga dengan fase larva yang terjadi pada fase grobogan (16,42 hari) (Tabel 2).

Tabel 2. Rata-rata fase larva dan pupa $H$. armigera pada empat varietas kedelai

\begin{tabular}{|c|l|c|}
\hline $\begin{array}{c}\text { Varitas } \\
\text { inang }\end{array}$ & $\begin{array}{c}\text { Rata-rata fase } \\
\text { larva (hari) }\end{array}$ & $\begin{array}{c}\text { Rata-rata fase } \\
\text { pupa (hari) }\end{array}$ \\
\hline Grobogan & $16.42 \mathrm{~b}$ & $6.45 \mathrm{~b}$ \\
\hline Willis & $13.04 \mathrm{a}$ & $5.83 \mathrm{a}$ \\
\hline Sinabung & $13.32 \mathrm{a}$ & $5.72 \mathrm{a}$ \\
\hline Gepak ijo & $18.49 \mathrm{c}$ & $7.48 \mathrm{c}$ \\
\hline
\end{tabular}

Keterangan: Angka dalam lajur yang diikuti oleh huruf yang sama, tidak berbeda nyata $(\mathrm{BNT}, \mathrm{P}<0.05)$

Perbedaan varietas umbuhan inang juga menyebabkan adanya perbedaan lama fase pupa $H$. armigera. Fase pupa yang terjadi pada varietas sinabung merupakan fase terpendek yaitu hanya 5,72 hari yang tidak berbeda nyata dengan lamanya fase pupa pada varietas willis yang 5,83 hari. Akan tetapi kedua varietas ini berbeda nyata dengan fase pupa yang terjadi pada varietas grobogan (6,45 hari). Fase pupa yang terpanjang terjadi pada vaietas gepak ijo yaitu 7,48 hari yang berbeda nyata dengan fase pupa pada varietas grobogan yaitu 6,45 hari (Tabel 2).

Tabel 3. Rata-rata persentase penetasan telur, larva instar 1 menjadi 2, instar 2 menjadi 3, instar 3 menjadi 4, dan pupa menjadi imago H. armigera.

\begin{tabular}{|l|l|l|l|l|l|l|}
\hline \multirow{2}{*}{$\begin{array}{c}\text { Varietas } \\
\text { inang }\end{array}$} & $\begin{array}{l}\text { Penetasan } \\
\text { Telur }\end{array}$ & $\begin{array}{l}\text { L-instar 1 } \\
\text { ke instar 2 }\end{array}$ & $\begin{array}{l}\text { L-instar 2 } \\
\text { ke instar 3 }\end{array}$ & $\begin{array}{l}\text { L-instar 3 } \\
\text { ke instar 4 }\end{array}$ & $\begin{array}{l}\text { L-instar 4 } \\
\text { ke pupa }\end{array}$ & $\begin{array}{l}\text { Pupa ke } \\
\text { imago }\end{array}$ \\
\hline Grobogan & $80,19 \mathrm{a}$ & $79,29 \mathrm{~b}$ & $77,15 \mathrm{~b}$ & $70,16 \mathrm{~b}$ & $60,23 \mathrm{~b}$ & $53,17 \mathrm{~b}$ \\
\hline Willis & $83,55 \mathrm{a}$ & $83,45 \mathrm{a}$ & $82,55 \mathrm{a}$ & $81.85 \mathrm{a}$ & $78,78 \mathrm{a}$ & $79.78 \mathrm{a}$ \\
\hline Sinabung & $85.37 \mathrm{a}$ & $86,77 \mathrm{a}$ & $83,34 \mathrm{a}$ & $80,83 \mathrm{a}$ & $83,65 \mathrm{a}$ & $85.86 \mathrm{a}$ \\
\hline Gepak ijo & $82,73 \mathrm{a}$ & $78,86 \mathrm{~b}$ & $71,11 \mathrm{c}$ & $64,45 \mathrm{c}$ & $52,12 \mathrm{c}$ & $43.30 \mathrm{c}$ \\
\hline
\end{tabular}

Keterangan: Angka dalam lajur yang diikuti oleh huruf yang sama, tidak berbeda nyata

$(\mathrm{BNT}, \mathrm{P}<0.05)$

Rata-rata persentase telur $H$. armigera yang menetas setelah diletakkan pada keempat varitas tanaman inang menunjukkan tidak adanya perbedaan yang berarti diantara keempat variatas kedelai tersebut (Tabel 3). Pengaruh perbedaan variatas inang terhadap persentase larva yang hidup/menetas mulai terlihat setelah telur menjadi larva instar 1 , pengaruh perbedaan varietas tanaman inang terus terlihat sampai larva sampai memasuki fase imago. Pada fase larva instar 1, persentase larva yang menetas memasuki fase instar 2 pada varietas sinabung dan varitas willis tidak berbeda nyata, tetapi berbeda nyata terhadap tanaman inang varietas grobogan dan kepak ijo sedangkan antara varietas grobogan dan kepak ijo juga tidak ada perbedaan (Tabel 3).

Persentase larva yang menetas dari larva instar 2 menjadi instar 3 sampai dengan 
persentase pupa yang menetas menjadi imago menunjukkan pola yang sama pada semua varietas tanaman inang tersebut. Persamaan polanya adalah bahwa pada varietas willis dan sinabung tidak ada perbedaan persentase yang menetas sampai pada fase imago, tetapi berbeda nyata dengan varietas grobagan dan varietas gepak ijo. Persentase larva yang menetas sampai memasuki fase imago berbeda nyata antara varietas grobogan dan gepak ijo. Selain itu tampaknya besarnya persentase telur yang menetas semakin lama semakin menurun pada varietas grobogan dan gepak ijo sedangkan pada varietas willis dan sinabung tampak persentase larva yang menetas memasuki setiap fase hidupnya selalu sama (Tabel 3).

Tabel 4. Rata-rata lama hidup imago dan keperidian $H$. armigera pada empat varietas tanaman kedelai.

\begin{tabular}{|l|l|l|}
\hline $\begin{array}{c}\text { Varietas } \\
\text { inang }\end{array}$ & $\begin{array}{c}\text { Rata-rata } \\
\text { lama hidup } \\
\text { imago (hari) }\end{array}$ & $\begin{array}{c}\text { Rata-rata } \\
\text { keperidian } \\
\text { (butir) }\end{array}$ \\
\hline Grobogan & $8,78 \mathrm{~b}$ & $71,2 \mathrm{~b}$ \\
\hline Willis & $11,23 \mathrm{a}$ & $139,5 \mathrm{a}$ \\
\hline Sinabung & $10,78 \mathrm{a}$ & $142,7 \mathrm{a}$ \\
\hline Gepak ijo & $7,34 \mathrm{c}$ & $50,1 \mathrm{c}$ \\
\hline Keterangan: & $\begin{array}{c}\text { Angka dalam lajur yang diikuti oleh } \\
\text { huruf yang sama, tidak berbeda nyata } \\
\text { (BNT, P < 0.05) }\end{array}$ \\
\end{tabular}

Berdasarkan hasil perhitungan terhadap waktu yang dibutuhkan untuk hidup pada fase imago dan besar jumlah telur yang dihasilkan oleh setiap betina (keperedian) serangga $H$. armigera pada keempat vaietas tanaman kedelai dapat dilihat pada tabel 4 . Lama hidup fase imago yang tersingkat terjadi pada serangga yang diletakkan pada inang kedelai varietas gepak ijo (7,34 hari) yang berbeda nyata dengan yang hidup pada varietas grobogan (8,78 hari) dan berbeda nyata dengan yang hidup pada varietas willis (11,23 hari) dan varietas sinabung (10,78). Lama hidup fase imago antara serangga yang hidup pada varietas willis dan varietas sinabung tidak berbeda nyata (Tabel 4).

Keperidian adalah jumlah telur yang dihasilkan oleh seekor betina sepanjang masa hidupnya. Rata-rata keperidian serangga $H$. armigera yang hidup pada tanaman inang kedelai dengan varietas yang berbeda memberikan hasil yang berbeda pula. Keperidian yang tertinggi terjadi pada serangga yang berkembang pada tanaman inang varietas sinabung yaitu 142,7 butir tetapi tidak berbeda nyata dengan yang berkembang pada varietas willis yaitu 139,5 butir. Keperidian tertinggi terlihat serangga yang berkembang pada tanaman inang dari varietas gepak ijo yaitu 50,1 butir yang berbeda nyata dengan serangga yang berkembang pada tanaman inang varietas grobogan yaitu 71,2 butir. Keperidian pada varietas willis dan sinabung berbeda nyata dengan keperidian pada vaietas grobogan (Tabel 4).

Bila diperhatikan secara keseluruhan hasil penelitian ini menunjukkan bahwa pada fase telur tampak lama waktu menetas dan persentase jumlah telur yang menetas tidak ada perbedaan yang nyata pada keempat varietas inangnya. Hal ini bisa dipahami karena semua telur berasal dari induk yang diperbanyak pada makanan yang sama yaitu tanaman tomat, sehingga persentase jumlah yang menetas dan lama waktu untuk menetas tidak berpengaruh. Selain itu faktor-faktor fisik atau faktor struktural tanaman inang yang berbeda tidak memberikan pengaruh yang berarti terhadap kedua parameter di atas.

Perbedaan yang nyata mulai terlihat pada semua fase larva, fase pupa, fase imago dan keperidiannya. Secara umum terlihat bahwa untuk semua parameter ini tanaman kedelai varietas willis dan sinabung tidak ada perbedaan, tetapi berbeda nyata apabila dibandingkan dengan yang berkembang pada varietas grobagan dan yang berkembang pada varietas grobogan berbeda nyata dengan yang berkembang pada varietas gepak ijo.

Berdasarkan hasil keseluruhan pengamatan terhadap semua parameter ini tampak bahwa yang paling berpengaruh negatif terhadap perkembangan larva $H$. armigera adalah varietas gepak ijo. Kemudian diikuti oleh serangga yang berkembang pada varietas grobogan. Diduga terganggunya perkembangan larva dalam hal penetasan, baik jumlah maupun waktu yang dibutuhkan untuk menetas dikarenakan oleh adanya senyawa-senyawa metabolit sekunder yang dimiliki oleh kedua varietas ini yang dapat menghambat ataupun mengurangi perkembangan larva, imago dan keperidian $H$. armigera. Dan metabolit sekunder yang dihasilkan tersebut tidak dihasilkan pada varietas sinabung dan varietas willis. 
Peranan metabolit sekunder dalam pakan sangat berpengaruh terhadap perkembangan serangga (Untung, 2001). Hasil penelitian yang dilakukan oleh Naseri et al. (2014) menunjukkan bahwa Helicoverpa armigera yang dipelihara pada berbagai kultivar tanaman kacang menunjukkan bahwa perbedaan kultivar inang memberikan hasil yang berbeda juga terhadap semua fase hidupnya dan tabel hidupnya.

Kesimpulan yang dapat diberikan adalah kacang kedelai varietas kepak ijo adalah varietas yang paling cocok untuk dikembangkan ketika serangga hama $H$. armigera meningkat. Karena varietas ini terbukti mengurangi persentase yang larva yang menetas dan jumlah keperidiannyapun sangat rendah.

\section{DAFTAR PUSTAKA}

Setiawati, W. 1991. Daur hidup ulat buah tomat, Heliothis armigera Hübner (Lepidoptera:Noctuidae). Bul. Penel. Hort. 21(3):112-119

Farrow, R.A. and J.C. Daly. 1987. Log-range movement as an adaptive strategy in the genus Heliothis (Lepidoptera: Noctuidae): A review of its occurrence and detection in four pest species. Aust. J. Zool. 35:1-24.

Fisher, A. E. I., Harteley, S. E. and Young, M. 2000. Direct and Indirect Competitive Effects of Foliage Feeding Guilds on the Performance of the Birch leaf-miner Eriocrania. J. Anim. Ecol., 69: 165-176.

Herlinda, S., L. Daha dan A. Rauf. 1999. Biologi dan Pemanfaatan Parasitoid Telur Trichogramma chilonis Ishii (Hymenoptera: Trichogrammatidae) untuk Pengendalian Helicoverpa armigera (Hubner) (Lepidoptera: Noctuidae) pada Pertanaman Kedelai dan Tomat. p. 23-32. In: Peranan Entomologi dalam Pengendalian Hama yang Ramah Lingkungan dan Ekonomis.Prosiding Seminar Nasional Perhimpunan Entomologi Indonesia Cabang Bogor Bekerjasama dengan Program Nasional PHT, Bogor 16 Pebruari 1999.

Jumar. 2000. Entomologi Pertanian. Rineka Cipta. Bandung
Liu, Z., Li, D., Gong, P. Y. and Wu, K. J. 2004. Life Table Studies of the Cotton Bollworm, Helicoverpa armigera (Hübner) (Lepidoptera, Noctuidae), on Different Host Plants. Environ. Entomol., 33: 1570-576.

Naseri, B., Fathipour, Y., Moharramipour, S.and Hosseininaveh, V. 2009. Comparative Life History and Fecundity of Helicoverpa armigera (Hübner) (Lepidoptera: Noctuidae) on Different Soybean Varieties. Entomol. Sci., 12: 147-154.

Naseri, B., Golparvar, Z., Razmjou, J. and Golizadeh, A. 2014. Age-stage , Twosex Life Tble of Helicoverpa armigera (Lepidoptera:Noctuidae) on Different Bean Cultivars. J. Agr.Sci.Tech. 16: 19-32

Uhan, T. S. dan R. E. Suriaatmadja. 1993. Pengendalian ulat buah tomat (Helicoverpa armigera Hubn.) dengan insektisida organophosphat dan pirethroid buatan. Bul. Penel. Hort. 25(4):29-34.

Untung, K. 2001. Pengantar Pengelolaan Hama Terpadu. Gajah Mada University Press. Yogyakarta. 